\title{
The Pilgrims' Route: The Star, the Cross and the Crescent
}

\author{
John Vella
}

\begin{abstract}
Ethnohistoric approaches to community history reveal that toponyms, legends and oral lore witness to unwritten, forgotten or excluded history. Archaeological artefacts and written documents likewise provide the evidence. Put together intangible and tangible heritage reveals that the ancient Maltese harbour served as a medieval port of call for pilgrims and travellers of the three monotheistic religions. The remnant from a 'cross column' recorded by a toponym served both social and religious purposes. Other toponyms in the locality witness to a thriving Jewish community, the short stay of a medieval Jewish philosopher and polymath, and royal correspondence witnesses to a long-standing passage of Muslim pilgrims. The research shows that the ancient harbour was both a cultural crossroad and a stage on pilgrimages to and from Eastern Mediterranean sites retained sacred by Jews, Christians and Muslims. Artefacts, place-names, oral lore and written documents are all remnants and mnemonics of past events and of a place where people of different cultures and creeds rubbed shoulders and lived in harmony to reach their destination. Today these sites and artefacts may still function as shrines for religious pilgrimage and be instruments which bring diverse people together.
\end{abstract}

Index Terms - Christian, Jewish, Malta, Muslim, pilgrimage, toponym.

\section{INTRODUCTION}

Toponyms sustained by tangible evidence enabled the identification and reconstruction of undocumented historic events [1]-[4]. In contrast to exclusive and subjective history, common people recorded and reminded their history through oral lore. The study departed from a documented toponym and searched for supporting evidence. The research revolves around the ancient Maltese harbour of Bormla (Bormla, known also as Citta' Cospicua: A title given by the Italian Grand Master Marc'Antonio Zondadari, 1720-1722).

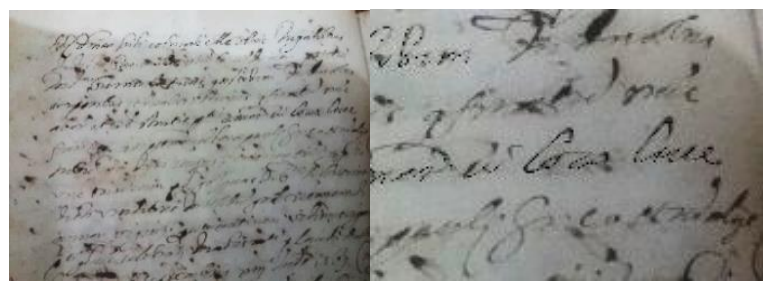

Fig. 1. Showing part of the contract and a close-up of the phrase indicated 'in loco cruce'.

The Bormla harbour [3] traces its origins to the Phoenician era [5] around $1000 \mathrm{BC}$ [6]. It became a harbour when sea-levels rose dramatically to change the coastline [4], [7]. The research sets off with a site-name recorded by Notary Andrea Albano [8] known as 'loco cruce': locally 'Is-Salib ta'

Manuscript received October 8, 2018; revised December 2, 2018.

John Vella is with the Mediterranean Institute of the University of Malta, Malta (e-mail: john.vella.13@um.edu.mt).
Bormla' [9], [10] (Fig. 1). The record dated 25 September 1588 by Albano for his clients Francia Michallef and Antonio Ros did not explain further about the 'burmula' site 'in loco cruce' and what it was meant to describe (Other authors mention a Notarial document by the same Andrea Albano dated 3 October 1590 on behalf of Francia Michalleff. Translation: 'at the place of the cross'). The author's earlier perception was that it referred to an intersection of ancient roads [3]. The exposure of the column (Figs. 2 and 3) in 2010 instead proved that a physical monument existed to mark a sacred site and to serve a social or religious purpose.

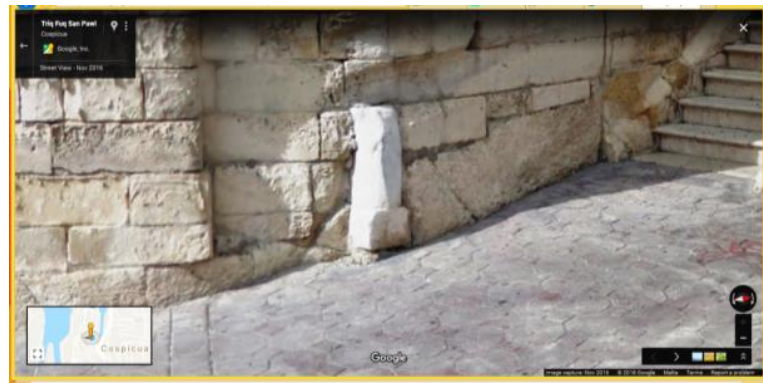

Fig. 2. The cross-column uncovered in 2010 is inserted between the rocks and the foundation blocks of the church. Picture: Courtesy of Google Maps street view.

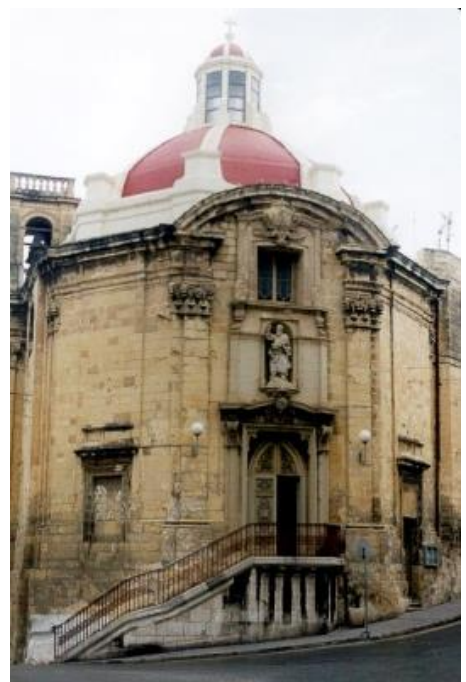

Fig. 3. The lower part of the church façade shows the white limewashes applied before 2010 .

It is yet unknown whether the 'cross' preceded the building of a church or accompanied an earlier shrine. Its integration within the rocky platform is proof of significant symbolic meaning or memories. The cross column could not simply be wiped off, discarded or destroyed for a church in either 1588-1590, in 1735-1741 (According to the Civil Acts of the Malta Curia [Atti Civili tal-Kurja ta' Malta] the laying and blessing of the first foundation stone was held on the $11^{\text {th }}$ August 1735 by Bishop Fra. Paolo Alferan de Bussan. The church was completed in 1740 and blessed in 1741) or any other time. 


\section{METHODOLOGY}

Through an ethnohistorical approach the study started by identifying cultural heritage, historic events, past practices, toponyms, legends, local lore and oral histories, artefacts and written documents connected to the case under study. It analysed both tangible and intangible heritage and, in some cases looked for connections or similarities on the Maltese Islands or the Mediterranean. In the case of the cross as the initial artefact tangible remains were looked for. The analysis indicated the erection of the cross to medieval pilgrimage and Crusader influences. In consequence the study found further popular lore, documents and site-names at Bormla which showed that the harbour was on pilgrimage routes not solely of Christians but of Jews and Muslims too.

\section{DISCUSSION AND FINDINGS}

\section{A. 'Cross' Toponyms}

To start with a number of toponyms on Malta include the word 'salib' (cross). At Mellieћa, a rural and fishing village in the north, one finds is-Salib tal-Pellegrin: Pilgrim's Cross. A recent memorial at Marsa is is-Salib tal-Marsa: the Marsa Cross. At Sigggiewi a cross adjacent to a hilltop chapel is is-Salib tal-Gholja: Hill's Cross. A legendary cross at Birkirkara is is-Salib ta' Rajt ma rajtx, Smajt ma smajtx literally 'the cross of what I've seen I haven't seen, what I've heard I did not hear'. A number of crosses on columns found in Maltese villages marked assembly points for the medieval Dejma (The Dejma was the mediaeval form of militia on the Maltese Islands. It consisted of villagers engaged and responsible for coastal and inland defence). A similar function to the 'cross of Bormla' as indicated in this study was only associated with the Mellieha cross, which formed part of a Marian pilgrimage route also associated to St. Paul's stay. Their position could have marked the start and end stages of the Christian pilgrimage on Malta.

\section{B. Christian Pilgrimage}

Tradition has it that Malta converted to Christianity with St. Paul's shipwreck in 60AD, but became overwhelmingly Christian at a much later date. The first Christian church at Bormla traced back to the Byzantine era (c. $8^{\text {th }}-9^{\text {th }}$ century AD) [11]. The memory of St. Paul's presence remained deeply rooted among communities and mariners who frequented the Bormla harbour [3]. Added to local lore narrated for generations and supported by the Acts of the Apostles through religous practices and reminiscence, the Christian community at the harbour could have erected a monument to remind of the Apostle's presence.

In southern Italy, ancient and Roman columns were re-used with a Christian symbol added on them to mark the site [12] and [13]. The recycled column at Bormla could have been already in place or erected after Byzantine monasticism reached Malta [3] but this is not supported by research. As the Byzantines arrived, the availability of Roman remains lying astray was highly potential, especially at Bormla's harbour [3] (Egyptian merchant ships travelled all year round between Alexandria (Egypt) and Rome using Malta as a port of call). Most remains have even survived into the late Medieval period when Latin-rite Christianity reached southern Sicily and then the Maltese Islands. The grey and pink Egyptian granite column (Pink Egyptian granite columns were transported from Egypt to various places under the Roman Empire. The column found at Malta was on its way to Sicily or Rome during the Roman era. Alexandrian vessels transported much more merchandise than wheat to Rome. The said column was left ashore as it was damaged when transported. Similar grey and pink Egyptian granite columns were exported and are found at various places around the Central and Eastern Mediterranean. A scholarly analysis could date the column at St. Angelo and find its similars in Sicily or Italy. Examples of such columns occur frequently in Sicily and Italy) left ashore on its way to Sicily or Rome and later recycled by the Order of St. John in the construction of St. Anne's Chapel at Fort St. Angelo is an example [14]-[18].

In 870AD Malta experienced the fundamentalist Aghlabid Arab occupation. No specific document stated that Christian memorials were either removed or destroyed. The forty-year long Aghlabid rule was unable to wipe off popular memories. The Fatimid Arab occupation in 909AD applied a tolerant approach to monotheists as Maltese Christians [19]. Circumstances permitted local Christians to re-use shrines or memorials as a pilgrimage stop for those who trailed on the footsteps of St. Paul or of early Christianity.

Another potential date for the erection, re-erection or addition of a 'cross' is the first half of the $10^{\text {th }}$ century AD, when the re-practising of local Christians was facilitated by the return of Byzantine clergy from Sicily [11]. Though under Norman rule, Muslims, Byzantine Christians and Jews enjoyed freedom, a most possible time for the erection of a permanent cross at this place of memory starts from the second half of the $13^{\text {th }}$ century, when many Muslims left Malta, and when the Angevin and the Aragonese took over. Witness to Malta being a port of call on pilgrimages to Rome and Santiago de Compostela comes from royal instructions dated 18 November 1373. King Frederick IV instructed all Maltese and Gozitan officials to assist three friars of the Augustinian Order of the Hospital of St. James of Altopascio. The Order was established in the $10^{\text {th }}$ century to assist pilgrims [20].

From the records of Notary Albano it appears that the cross was known, celebrated and in place till 1588 [21]-[23]. If not the physical cross as such, the toponym survived to witness its former presence. It is unknown whether the cross was always at the same place where its remains are today or at another spot adjacent to the church. Research through art could only provide an 1829 drawing by Owen Browne Carter showing a view from the street opposite the church when the church still had a stepped parvis [24].

\section{The Cross and the Dejma}

In Malta, cross columns gained importance due to their mediaeval function as is-Salib tad-Dejma (Translation: The local militia's assembly cross.). Both Church records at Mdina [25] and other scholars [26] retain that the Dejma started in 1462 [27]. Nonetheless similar defence teams existed during the Arab occupation five centuries earlier. An earlier militia is mentioned in 1419-1420 at Mdina [28]. Although Bormla males formed part of the Dejma, no written record specifically referring to Bormla was yet encountered till the $15^{\text {th }}$ century. It results that the Bormla harbour 
communities were referred to collectively as the harbour communities or contradas. If the Bormla cross was an assembly point for the medieval harbour militia then it pre-dates the Dejma crosses by at least two or three centuries, into the Norman rule.

Considering that the new Borgo (Birgu) was built by the Order some years after 1530 (Fig. 4), references to a harbour area Dejma or militia prior to that time actually referred to the older borgo (suburb), formed by the communities at Bormla, any community at Isla (Senglea), and close-by communities at hamlets which later formed Haż Żabbar. Haż Żabbar formed an autonomous group in 1498 [29] as its population increased and invasions from southern harbours became frequent.

In 1530 the Order took over military command and operations on the Islands. The existence of a Compagnia company of guards [30] - set up by the Bormla communities is mentioned several times in the 1565 Great Siege events [31]-[33] (The Burmola company was joined with the Senglea company and were in all 300 men. If the statistics of 3,000 soldiers drawn from the Maltese population is correct then it means that $10 \%$ of the Maltese troops (around 1,000) hailed from Bormla and Senglea, and thus forming the pre-1565 type of militia or Dejma). Well-documented the Compagnia engaged in battle against the Ottoman army and other missions led by a master or captain [31] before retreating behind the new walls of the new town [31] (The Birgu in 1557 is described as 'Citta' nuova' (new town) and in 1565 its fortification is described as 'muraglia nuova' (new walls)).

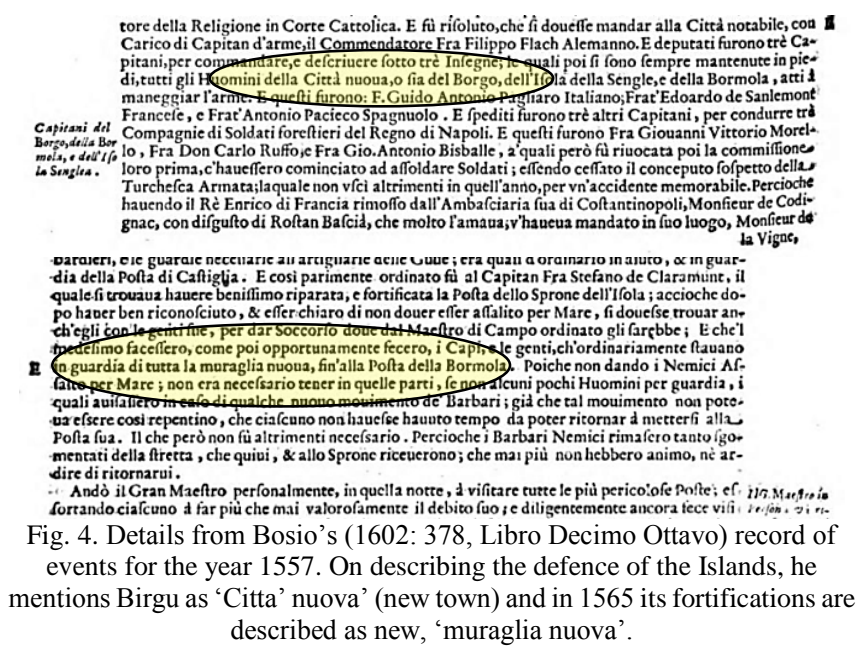

It is believed that the cross was either taken to Mdina by Church authorities prior to the Great Siege or it was pilfered, destroyed or vandalised by the invading Ottoman army. The column base survived as it remained in place integrated with the churches built in 1588-90 [3] and 1735-1741. No further reference to a re-installation of the cross was found afterwards. The community retained the Apostle's memory through the church and the column base attached to it. Local lore has it that the Apostle preached on the same rock before embarking on an Alexandrian vessel to Rome in 61AD.

At the end of the $19^{\text {th }}$ century, lime-washes were applied over the column and the rocky platform. This was altogether a curse and a blessing as the artefact was preserved till present but gradually forgotten and erased from the memory of passers-by. In 2010, the restoration of the church façade re-exposed the column. The stepped parvis was removed in the $20^{\text {th }}$ century to make way for vehicular traffic, but a detail on the parvis could be the cross column at that time. (Figs. 5 and 6).

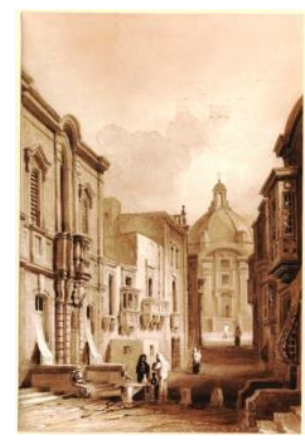

Fig. 5. A drawing by Owen Browne Carter (1829) showing St. Paul's Street and Church at Bormla, Malta

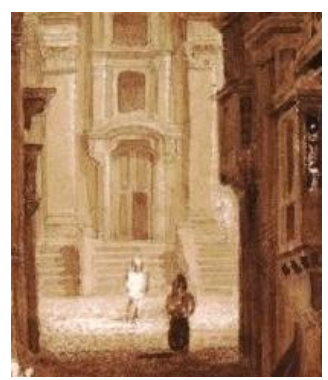

Fig. 6. The close-up shows the stepped parvis of the church prior to its removal in the late nineteenth century to make way for the road. It is the detail (circled) on the right could be the earlier position of the cross column.

\section{Archaeology}

The column itself is an unique archaeological artefact. Inserted between the rocky platform and the foundation courses it stands on the east façade of the church overlooking the wharf. It demonstrates characteristics similar to the croci viarie or stazionarie found around southern Italy. A cross similarly inserted into its adjacent building is found among others at Longano (Molise, Italy) and was dated to the $13^{\text {th }}$ century [34]. (Fig. 7). A cross-column of similar shape was recently unearthed at Cercemaggiore (Province of Campobasso, Italy) (Fig. 8) [35]. It must be noted that in 1221 the communities of Celano and Rocca di Mandolfi (Molise) were deported to Malta [36]. Most crosses form part of Christian pilgrim trails between European sites and the Holy Land via the southern Ionian harbours [37].

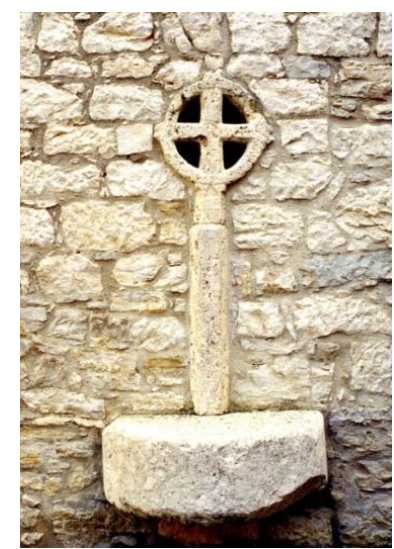

Fig. 7. Cross at Longano (Molise) incorporated with the building adjacent to it. Photograph: Courtesy of Franco Valente. 


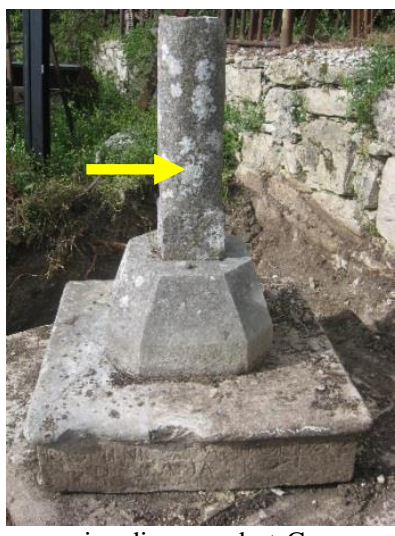

Fig. 8. Cross-column remains discovered at Cercemaggiore (Campobasso, Italy). Notice how the section marked with a yellow arrow resembles the cross-column remain at Bormla. Photograph: Courtesy of Stefano Vannozzi (2012) in [35]

\section{E. Similarities in Southern Italy}

Most $15^{\text {th }}$ century Dejma cross-columns on Malta and Gozo were hewn from globigerina limestone not from hard coralline limestone or marble. The search for similar or comparable hard coralline limestone or marble cross columns around the Maltese Islands was futile but proved fruitful in southern Italy. Most of southern Italy formed part of the Sicilian Kingdom to which Malta was annexed for centuries. Roadside crosses (in Italy known as croce viaria or croce stazionaria) which dated between the $9^{\text {th }}$ and the $13^{\text {th }}$ centuries in southern Italy served as guides to travellers or to mark stages on pilgrimage routes as that toward Santiago de Compostela [38], [39]. Stone crosses were erected to mark a sacred site or of religious significance especially on pilgrimage routes. It was meant to repel evil and misfortunes from the area where it stood. Crosses received significant attention and reverence in places connected to Christianity. They were placed were life was busy and where many people interacted [37].

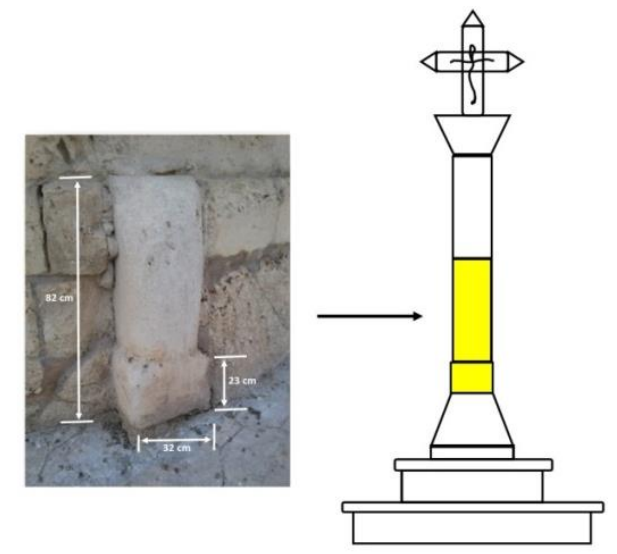

Fig. 9. Author's impression of how the cross-column might have looked in medieval times. The surviving section shown in yellow. Measurements: 82 $\mathrm{cm}$ total height, $32 \mathrm{~cm}$ width, and base height is $23 \mathrm{~cm}$. The design was inspired by the studies of Stefano Vannozzi (2012) in [35].

Similar crosses erected in the $11^{\text {th }}$ century in southern Italy were located at social places, main squares and marketplaces, on important and busy pathways or intersections of streets, at the entry or arrival point of a country, in order to guarantee sacred protection. Such spaces were held as important to both civil and religious authorities and none dared lose them totally to the other. The crosses served as a place for dealings in the absence of notarial or legal documentation: trading deals, verbal contracts and agreements were sworn in front of them, with full obligations and duties as if sworn and written in front of a notary. The erection of such crosses became popular with pilgrimages and were already mentioned as markers by the time of the first Crusade [40] (Fig. 9).

Crosses witnessed to a system of old thoroughfares and were sometimes linked to toponyms [41]. They showed herdsmen the way to the Adriatic and pilgrims the sites of pilgrimage. They were placed in visible spots on high grounds, at crossroads, at staging points, at places where the herds were gathered or at the entry point to a country [41]. The presence of a cross at Bormla validates its role as an ancient and medieval harbour, an entry point of Malta and a pilgrimage site. The acknowledgement of Malta as a port on the route to the Levant is among other proved by $17^{\text {th }}$ century cartography [42]. Placed at a then prominent visible spot for those arriving by sea the cross was of an etnoanthropological importance, of historical interest and a popular artistic expression [41]. Before the $16^{\text {th }}$ century, crosses served as a refuge for those escaping justice, until the Church lifted such privilege on sacred places. Crosses happened on routes to the Holy Land and other important pilgrimage sites, inclusive of itineraries which ran through southern Italy [37]. Sicily and Malta were no exception on pilgrimages going East or West.

\section{F. The Crusades}

Some attributed the crosses to the Knights Templar or the Byzantines, but this does not hold as a theory [43], even if the Byzantine monks' presence at Bormla is traced back to the $8^{\text {th }}$ century AD [11]. Most of the undated crosses constructed from recycled Roman columns are attributed to the $11^{\text {th }}$ century when Crusades and pilgrimages became popular. For centuries both Syracuse and Bormla acted as ports of call on voyages to and from Leptis Magna (Libya), Alexandria (Egypt) and the Holy Land. Based on earlier findings references to the Malta harbour community were specific of communities at Bormla [3], where the Pauline memory and Byzantine Christianity contributed to early Christian pilgrimages [44].

If the Crusade connections were sustained, a possible dating of the cross would be when Crusades included Malta on their route. A first possibility is during the $3^{\text {rd }}$ Crusade (1189-1192) when Malta became a Genoese fief and most participants sailed from Genoa to Syracuse and Malta. A second was the late $13^{\text {th }}$ century Crusades which planned the capture of Egypt and the Bay of Tunis. Two other Crusades which could have harboured at Malta were those by Emperor Frederick II of Sicily (1228-1229) and the French Monarch Louis IX (1248-1254). All of which were further facilitated by the Genoese presence [3] (The Genoese used Malta as a fief granted to them by the Sicilian monarchy between 1174 and 1224. The Seventh Crusade would have reached Malta, and harboured at the Bormla harbour in 1248. It can therefore be possible that those voyaging on the sea-vessels had to reside for some time with the people of Bormla. Witness to such are the Crusader bulla and the graffiti of Templar crosses found at the Bir Mula Heritage museum site).

\section{G. Knights Templar Connection}

Evidence of Knights Templar and Crusader connections 
comes through graffiti and artefacts found at the Bir Mula Heritage museum site (The museum, a private initiative, is at 79, St. Margerita Street, Bormla, Malta. Among the artefacts on exhibit is a Crusader bulla dated to the $12^{\text {th }}$ century AD). Besides a Crusader bulla (seal) dated to the $12^{\text {th }}$ century AD, the house preserves graffiti of a number of Templar crosses on two levels constructed prior to the $15^{\text {th }}$ century and the 'flower of life' (The 'flower of life' is also considered as a symbolism of the universe and a representation of Homer's windrose (c.800BC) used in classical navigation. By time its original significance decreased and was only considered as a geometric drawing.). The crosses etched on doorways and walls are like those used by the Knights Templar from the mid- $13^{\text {th }}$ to the $14^{\text {th }}$ century (Similar $13^{\text {th }}$ century crosses are found on frescoes in Italy. After the persecution years 1307-1314, in 1319 the Knights Templar re-established at Tomar (Portugal) and sailed the seas on their fleet. At Bir Mula Heritage (BMH) museum together with the 'cross' graffittos is script identified as Neo-Punic and another as Paleo-Hebrew. An 'MM' graffito is attributed to the memory of Mary Magdalene. Some claimed that Mary Magdalene resided at the harbour for a short while on her voyage between Egypt and southern France. Other graffittos at BMH include symbols found in $13^{\text {th }}$ century Templar churches as that of San Bevignate, Perugia, Italy. The 'fiore della vita' [flower of life] symbols are in the first section of the entrance hall.). The pilgrimage and Templar connections were enhanced with the recovery on site of a $12^{\text {th }}$ century Crusader bulla (The Crusader bulla is now preserved at the Bir Mula Heritage museum at Bormla. The dating attributed to it is the late $12^{\text {th }}$ century $\mathrm{AD}$. It was found in a sample of silt taken from the rain-water sump at the courtyard of the museum in 2002). The bulla is retained as another tangible evidence of how the Bormla harbour featured among Christian pilgrimage sites (Treccani Biografie, Italy, 2017. Under 'Enrico di Malta' it states that "Malta, un importante porto di scalo per i mercanti genovesi in viaggio per la Terrasanta o per l'Egitto, faceva parte del Regno normanno di Sicilia." ... "La reazione di Pisa non si fece attendere e il nuovo conte di Siracusa si vide costretto a chiamare in aiuto il suo concittadino Enrico. Questi venne con quattro galere e due navi genovesi che stavano ritornando dalla Terrasanta, ed insieme sconfissero nel dicembre 1205 i Pisani nel porto di Siracusa." Thus indicating that Malta was on the route of Christian pilgrims. Available http://www.treccani.it/enciclopedia/enrico-di-malta_\%28Diz ionario-Biografico\%29/). Simultaneously, the bulla demonstrates that even if the house at Bormla was resided by a family who for survival purposes presented themselves as Muslims, they still gave shelter to declared Christians on their way to or from pilgrimage sites in the Mediterranean. The Pauline devotion had gradually decreased especially among foreigners but survived among locals through oral lore. In this scenario the written and tangible evidence of both toponym and column respectively is fundamental. The reasons for a decline in the arrival of Christian pilgrims were many. The turbulent Mediterranean situation saw an increase in hostilities from ruling and contending powers.

From the mid $-15^{\text {th }}$ century, the Roman Catholic Church became strong in Malta. By hook or by crook, it ousted and obliterated most of the past remains and constructed images of a fervent ages-old Latin-rite Christian identity. Simultaneously it created strong rifts between harbour communities, administrative centres and authorities claiming power on the Maltese political scenario. Certainly, religious authorities of whatever creed, in many situations acted politically and endeavoured after temporal interests rather than the spiritual. History is full of accounts and events where religion and politics interrelated or clashed. Due to their human nature some made temporal power as their main objective, acted at the expense of their institution and religion: sowing hate, divisions, conflicts, exclusions, wars and death.

\section{H. Jewish Pilgrimage}

Another inspiring toponym which survived as an oral tradition comes from the local elderly. The elderly narrate that they played in a rock-cut tunnel which existed till 2000 2001 (The tunnel hewn from an older cave-dwelling was at the spot where the west part of St. Helen Street runs under the fortification wall. The Rambam tunnel was destroyed to build government social housing blocks in 2000-2001, even though the attention of the authorities was drawn by the local community). In the $17^{\text {th }}$ century (c.1638) the cave-dwelling was dug into a tunnel allowing access beneath that section of the St. Margerita Lines. The tunnel was locally known as 'Il-Mina ta' Rambambam' literally 'the tunnel of Rambambam'. (Fig. 10)

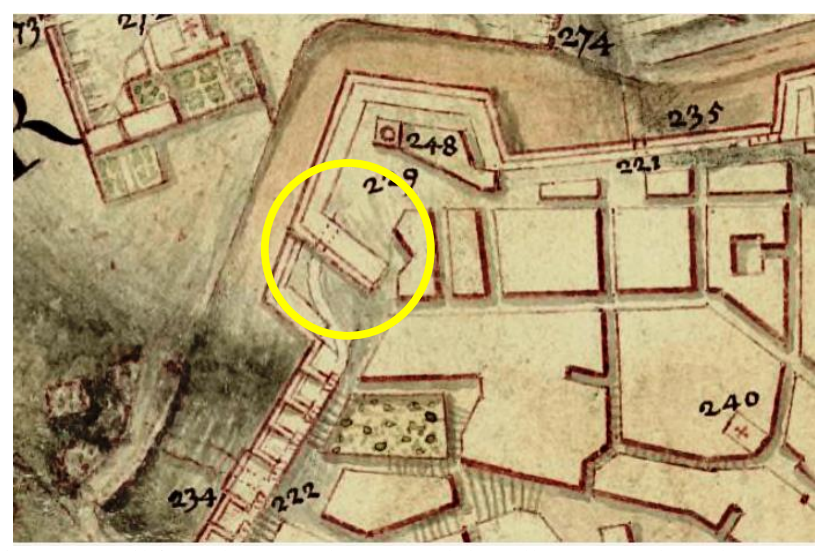

Fig. 10. Detail from the map Plan général des villes et forts de Malte... (1799) by Georges Grognet (Bibliotheque Nationale de France, Paris) showing the tunnel known as il-Mina ta' Rambambam, beneath the St. Margerita fortifications, Bormla

Interpretation and meaning were unclear among the younger generation who said the tunnel was so called because it echoed (Verb: rbombja in Maltese). The elderly maintained that it was named after a medieval pious person who lived there when it was still a cave-dwelling. This led into further research among records of pious persons or pilgrims who could have reached Malta for some time in history. Though no record of a 'Rambambam' was retrieved among Christian saints, hermits or pious persons, a much corresponding name came from another monotheistic faith. Rambambam happened to be a local colloquial derivation, reference and memory of the prominent $12^{\text {th }}$ century Jewish Rabbi Rambam known as Maimonides. (Fig. 11)

Rambam was born in Cordova (Spain) in 1138. On the invasion of the fanatic Almohad Muslims in 1147-1148, Jews in Spain were either to stay and convert to Islam, or else be exiled. After escaping to the mountains, where they lived in caves till 1154, the Maimonides family left Spain, sailed to 
Tangiers (Morocco) and settled in Fez. In Fez, they met numerous refugee families who fled from Andalusia (Spain) and from Kairouan (Tunisia) which became an important Muslim pilgrimage site.

The presence of Kairouani refugees in Fez inspired Rambam to travel eastwards along the same route to Tunisia. Rambam went eastwards towards the Holy Land in 1164 1165. Based on knowledge gathered from Tunisian mariners, and since survival was crucial for his family, Rambam chose to sail to Malta.

Since the 1127 reconquering of Malta by the Normans and the coming of Roger II into power in 1130, Malta returned to form an integral part of the Norman Sicilian Crown. It enjoyed a more lenient and tolerant rule, increasing European connections but decreasing Arab influence and authority on the Islands. This gave Rambam's family a deep breath and time to recuperate after their journey from Fez to Tunisia. It was safer for them to travel away from the troubled, declining and fragmenting Fatimids and any Arab Muslim rule which dominated the North African coast.

The time spent on the journey from Fez to the Holy Land indicated that Rambam and his family spent the winter of 1164 - 1165 on Malta before embarking eastwards. In 1166, they moved to Alexandria where Rambam became the respected physician of Saladin. Rambam was equally loved by Jews, Muslims and Christians. He was considered as the first ever philosopher to have rationalised and unified religion, God and philosophy into a living and understandable synthesis [45].

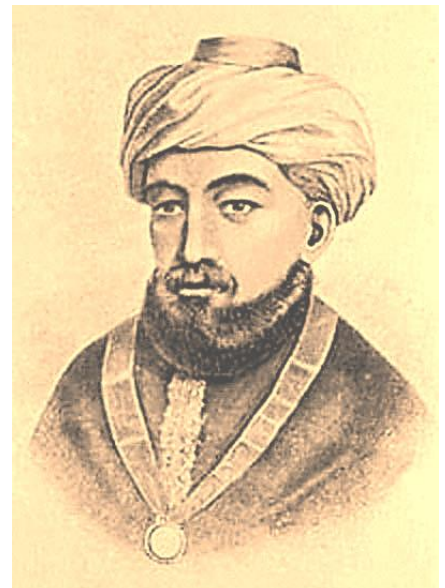

Fig. 11. Traditional portrait of Rabbi Rambam known as Maimonides (1135 - 1204).

The Malta route is quite evident and straightforward. Malta, especially the Bormla harbour, served as a port of call for Alexandrian vessels since Roman times [3]. Rambam and his family wintered on the Island and found temporary refuge in a cave-dwelling overlooking the inlet. It was and still is common among Mediterranean communities to have cave-dwellings forming part of a house.

Rambam had no intention to reside on Malta for long. Malta for the Maimonides was only a port of transit on their way to Alexandria. Irrespective of religious and political pressures, their memory was kept by the community at Bormla who maintained the toponym as a reminder of the prominent Jew whose image and works unified the monotheistic creeds.
The possibility of Jewish pilgrims visiting the place of Rambam's stay after the $12^{\text {th }}$ century could not have survived independently from knowledge about the figure of Rabbi Rambam at his time or at a time after his departure from Malta. The memory of Rambam survived through the toponym and local lore, the medieval Jewish community and Jews who knew about Rambam and his works (Another Jewish personality who based his writings on Maimonides was Abraham ben Samuel Abulafia who was exiled on Comino from Sicily after being accused of declaring himself a prophet and messiah. Arriving to Malta in 1285 he would have harboured at Bormla visiting the site of Rabbi Rambam whose teachings he held in high esteem). Certainly, the persecution of Jews in Malta in 1492 and later hostilities impacted heavily on preserving the memory of Rambam.

A remnant of the Jewish presence at Bormla is the toponym of the Ghajn Dwieli valley which is a reminder of the Ein Karem village close to Jerusalem. Both toponyms translate into the 'valley of vineyards.' On the headland upon which Birgu was later built, the Jewish presence was also proved with a synagogue, which overlooked the Kalkara creek. The synagogue was abandoned between June $18^{\text {th }}$ and September $18^{\text {th }}$, 1492 after the expulsion decree signed in Palermo, with pressures from Aragon and the Roman Church, gave the Jews in Malta and Sicily three months to either leave or convert to Christianity and renounce 45 percent of their possessions. On June $2^{\text {nd }}, 1496$ the Benedictine nuns were given the ex-synagogue property to build on it their monastery [46]. However, it seems that the Palermitan administration did not fully adhere to the Aragonese orders. It acknowledged and protested on the expulsion of Jews as it would have impacted negatively on the economy and commerce of both Palermo and the Maltese Islands. The high number of Jewish converts to Christianity in Sicily shows that a stratagem for survival was somehow agreed between the Palermitan authorities and the Jews themselves in Sicily and its domains including Malta. Though the Jews officially and statistically almost disappeared, mostly as converts, it is evident that they established themselves quite strongly within the community and the commercial opportunities at Bormla for another two centuries. A most valid witness to the presence of a thriving Jewish community at Bormla was an old Jewish cemetery which existed till 1719 on the St. Margerita Hill, south of the site known as Ta' Gebel el Bar [4]. In Arabic the toponym of the site means 'the hill of the mainland' thus a landmark indicating the safehaven or harbour of shelter for navigators. The toponym reinforces the meaning of the Bormla toponym as the ancient Malta harbour of refuge [3], [6] (Note: A similar toponym is that of Ras el Bar, Egypt, and which attributed to local sailors, the term Ras el Bar referred to the place as the shelter place from sea storms. 'Ras' (head) is the start or beginning and 'el Bar' is the land, and therefore the head of the land or in maritime definition a harbour of refuge). Though the site is now partially taken by a road and an inaccessible section adjacent to what was the Rock Gate of the St. Margerita Lines, no mnemonic was ever raised after that date to commemorate the cemetery, which according to local lore served also as a burial ground for Ottoman casualties in 1565 . In the $19^{\text {th }}$ century, Royal Navy patients who died at the Cotonera British Military Hospital (now St. 
Edward's College) at Bormla were also buried there. Of interest is the fact that the Jewish cemetery for ransomed Jewish slaves at Kalkara, was established in 1784 (March $1^{\text {st }}$ ) by a Livorno Jewish fund, just outside the traditional Bormla confines which once arrived to the valley separating the Ta' Pażan Hill from the adjacent Bighi hill.

The high and late medieval (1001-1500) and the early modern period (1500-1800) were characterised by persecutions and expulsions among the monotheistic religions. These struggles were supported by regents and rulers who wished to maintain their power. Submission to religious authorities was unavoidable to avert further trouble. While clashes about ownership of the Holy Land and other Mediterranean strategic lands increased, Christians got involved in several conflicts. Muslims were equally engaged in fighting the Crusades. The Jews became entangled and held as either supporters or a threat to both. Considering all factors, religion did not matter more than the temporal and material wealth which rulers on either side looked for. Religion was only a comfortable excuse to gain the support of the masses. Dealings between the Aragonese Crown and the hierarchy of the Roman Catholic Church intensified efforts to expel Muslims, persecute Jews and erase their memories. The memory of Rabbi Rambam could have suffered from two factors. It was either subjected to ridicule intentionally by those intending to promote a different memory or was unintentionally messed up by vernacular factors through time [48]. Yet Rambam's route from Tunisia to Alexandria and the Middle East, via Malta is proof of the maritime route which for centuries carried merchandise and pilgrims including Muslims - to and from the pilgrimage sites of the monotheistic creeds.

\section{The Muslim Pilgrimage}

It is evident that Muslim pilgrims used the Malta route during the Arab occupation (870-1091) of the Islands and through the years of their strong presence (till 1224). Problems rose afterwards when the Islands were under rulers subjected to various pressures. During the late $12^{\text {th }}$ and early $13^{\text {th }}$ century Malta's harbour was an important port of call for Genoese merchants going to the Holy Land. Its importance on pilgrimage routes is later recorded in the mid- $16^{\text {th }}$ century and the $18^{\text {th }}$ century. The Ottoman Sultan, Soleiman the Magnificent, (Fig. 12) complained in a letter to Admiral Turgut Reis (Admiral Turgut Reis, is known as Dragut among the Maltese. He was the Chief Governor (beylerbey) of Algiers and Chief Regional Governor of the Mediterranean) (Fig. 12) that the route through Malta used by Muslim pilgrims and merchants who navigated the Eastern Mediterranean to Egypt was blocked [49], [50] by the arrival of the Order (Istanbul State Archives, Entry 565, letter from Soliman to Hasan, beylerbey of Algiers, undated (assumed by the author to have been written between 2 and 30 Cemaziyelevvel 972, between December 1564 and the month of January 1565)), (Istanbul State Archives, Entry 868, Soliman's letter to the Crimean Khan). Consequently the Sultan ordered Ottoman attacks on Gozo (1551) and Malta (1565) respectively [51]. Two centuries later Muslim pilgrimage was not only disrupted but also pilgrims were captured and forced into slavery by practices of piracy, corsairy, economic interests and pressures of political and religious allegiances embraced by the Hospitaller Order [52]. These occurrences were nonetheless occasions for the harbour communities and the captured to come into contact.

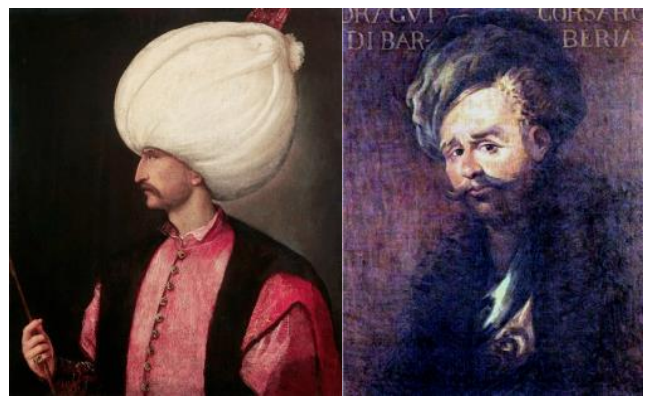

Fig. 12. A portrait by Tiziano (1530) of Soleiman the Magnificent or the Lawgiver, Sultan of the Ottoman Empire between 1522 and 1566, (left), and a $16^{\text {th }}$ century portrait by an unknown artist of Turgut Reis known as Dragut, Ottoman Greek Admiral, Chief Regional Governor of the Mediterranean and privateer (right)

Witness to activities and co-existence of religions and cultures at the Bormla harbour were the cemeteries and temples identified in its proximities. Historically Bormla consisted of a number of small villages, namely contrade [4], set around the harbour activity and facilities. Great Siege maps (1565) and various documents prove that the Bormla habitations spread from the St. Margerita Hill close to the site of the present Dominican Priory (Birgu), all around the creek, on hills, and reaching into present Senglea. The small communities had even provided spaces for burial outside the inhabited areas. Cemeteries were divided on matters as culture or creed. Some were intended to rest the corpses of those who died on board or while at harbour.

The Christian burial ground was in the area now comprising the church of St. Lawrence and the main square of Birgu. These cemeteries were removed by the Order after 1530 to build their new conventual church and new suburb 'Borgo Nuovo'. Witness to a small Jewish community close to the Bormla harbour area was the synagogue which remains existed till June 1496 on the north-east shore of the Birgu peninsula where St. Scholastica's Cloister now stands (The synagogue abandoned in 1492 and already derelict in 1496 was destroyed on orders of the Vatican to build a hospital now St. Scholastica's Benedictine Nunnery. It is retained that when in 1400 King Martin I of Sicily granted freedom to all Jews, a couple of Jewish families from Hal Bajjada (Rabat) or Mdina went to build their houses close to Bormla to share in the wealth generated by the activities at the maritime harbour. Repeatedly persecuted and harassed they gave up and moved elsewhere) [53], [54]. Hospitals and cemeteries were situated at a distance from the inhabited areas. The existence of cemeteries and a hospital on the Birgu peninsula in 1530 is proof of its being uninhabited and void of houses (Foglierini states that those who arrived with the Order in October 1530 were forced to live in fishermen's huts not houses) [51]. Its vacant land permitted the Order to build its new borgo (now Birgu) without raising discord among the harbour communities at the older borgo of Bormla, with that of the St. Margerita contrada being the closest. Archaeological tests carried around Birgu and its seabed in the $19^{\text {th }}$ and late $20^{\text {th }}$ century had only rendered artefacts dated after the Order's arrival [55] and [56]. Though the Knights of St. John built hospitals within their fortified and inhabited towns the British 
in the $19^{\text {th }}$ century still situated hospitals and cemeteries away from urbanized areas.

Sanctioned obliteration and desecration of Arab or Muslim remains on Malta made tangible evidence rare, except for some tombs discovered in Rabat and at the Marsa. Local lore at Bormla has it that the Rock Gate area served as a burial ground for Ottoman forces including accompanying Jews, Greeks, Albanians, Africans and others who died during the Great Siege. All this implores that any surviving remnants of the three monotheistic creeds, their presence, activities and practices on the Maltese Islands, are well-preserved and studied as they throw light on unrecorded history.

\section{CONCLUSION}

The ethnohistoric research concluded that the toponyms 'is-Salib ta' Bormla', 'il-Mina ta' Rambambam' and Soleiman's correspondence incorporate with them a considerable amount of history about the Bormla harbour, about the three monotheistic pilgrims, personalities and travel, which were previously unrecorded. Notwithstanding the pressures of the powerful for the production of subjective histories, toponyms survived through memories, legends and local oral lore that is sustained by primary tangible archaeological evidence and written records.

The only remain from the actual ' $i$ s-Salib $t a$ ' Bormla' is therefore an important landmark of local ethnohistory, of Maltese history, and Mediterranean history. It brings together memories of an age when the three monotheistic faiths, in contrast to their struggles elsewhere around the Mediterranean, coexisted and supported each other at the Bormla harbour. In spite of the different cultures and colonisers ruling over the Maltese Islands, the ancient harbour community was a welcoming destination to pilgrims and travellers of different creeds and origins. As the works of Rabbi Rambam became a symbol of unity among the three monotheistic creeds, the tangible and intangible heritage at the ancient Bormla harbour can once again through religious pilgrimage and tourism bring people of different cultures and creeds together.

The cross column is both a religious and a social landmark which demands immediate protection and preservation for future generations and for researchers from a myriad of disciplines which can come together to discover more about the history of ancient harbour communities and the Mediterranean. Exceeding the limitations imposed by languages and access to resources, further research, and expert archaeological studies of such sites can certainly provide more about the subject in question. The ethnohistoric approach and findings inspire historians to revisit and to rewrite history as it happened in contrast to previously obfuscated subjectivities and exclusions.

\section{ACKNOWLEDGMENT}

The Author would like to thank his family for their patience and support during the time of research.

\section{REFERENCES}

[1] H. A. Derek, "Naming and the interpretation of cultural landscapes," in The Ashgate Research Companion to Heritage and Identity, B. Graham and P. Howard, Ed. Ashgate, 2017, p. 196.
[2] J. Nash, "Pristine toponymy and embedded placenames on islands," A Journal of Onomastics, vol. 60, no. 3, pp. 166-167, September 2012.

[3] J. Vella, "Thalassic imaginaries: Silent witnesses to (an) unwritten history?" presented at the Conference Thalassic Imaginaries: the Mediterranean Sea in Language, Art and Other forms of representation, Mediterranean Institute, University of Malta and the Institute for Mediterranean Studies, Busan University of Foreign Studies, South Korea, Mediterranean Institute, University of Malta, Malta, January 23-24, 2015.

[4] J. Vella. (2016). Homer's Ogygia: An imaginary or a historiography? Athens: Atiner's Conference Paper Series. [Online]. Available: http://www.atiner.gr/papers/MDT2016-2007.pdf

[5] J. Smith, The Voyage and Shipwreck of St Paul, London, U.K., 1848, p. 285.

[6] J. Vella, "How the Maltese islands got their names: Malta, its ancient harbour and Comino," Part II of two papers (unpublished), 2017.

[7] J. E. Oliver, "The encyclopedia of world climatology," in Encyclopedia of Earth Sciences Series, The Netherlands: Springer, 2005, p. 259.

[8] Valletta: Notary Andrea Albano, Notarial Archives of Malta, (1582-1636), 25 September 1588.

[9] A. Albano (1582-1636), Notarial archives Malta, 'Revenditio' [Resale] 25 September 1588. (f.69 retro) between Francia [Francesca] Michalleff and her husband Nicolaus to Antonio Ros mentions a site at la burmula (Bormla) known as 'loco cruce'. Literally meaning 'the place of the cross'.

[10] C. G. Scannura, Taghrif Storiku Dwar il-Knisja Parrokkjali ta' Bormla, Bormla, Malta: Kummissjoni Fuljett tal-Kunsill Parrokkjali, 1983, p. 5

[11] J. Vella, (2016b), "The rock-cut church of Bormla: Origins and developments influenced by mediterranean and local history," Journal of Maltese History, vol. 5, no. 1, 2016.

[12] M. S. C. Mariani, Croci Viarie in Capitanata Lungo la via Francigena, Extracted from Dulcius Nil est Mihi Veritate, Foggia, 2015, p. 156.

[13] F. Valente. Croci stazionarie nel Molise. Gli architetti di Dio. [Online] Available:

http://www.francovalente.it/2008/12/08/croci-stazionarie-nel-molise/

[14] Gianfranco, "Vincenzo Tusa e gli esordi dell'archeologia subacquea nella sicilia occidentale," Dipartimento IURA, Universita' di Palermo, Sicily, 7 June 2009, p. 2.

[15] D. Chateaubriand et al., L'Italia Descritta e Dipinta con le sue Isole di Sicilia, Sardegna, Elba, Malta, Eolie, di Calipso, ecc, 2nd ed. Torino, 1837, p. 78

[16] G. Ferro and R. Mazzaresi, Guida Per Gli Stranieri in Trapani con un Saggio Storico, Trapani: Mannone e Solina, 1825, p. 343.

[17] M. Prunetti, Viaggio pittorico-antiquario d'Italia e Sicilia, Rome: Lino Contedini, 1820, pp. 55, 70, 159.

[18] J. L. Burigny, Storia Generale di Sicilia, Illustrate con Note, Addizioni, Tavole, Cronologiche; e Continuata Fino a Nostril Giorni, translated from French by Mariano Scasso e Borrello, Palermo: Stampe del Solli, 1788 , p. 213

[19] J. Wintle, History of Islam, London: Rough Guides Ltd., 2003, pp. 136-137.

[20] C. Savona-Ventura, "Historical perspective - Hospitaller activities in medieval Malta," Malta Medical Journal, vol. 19, issue 03, p. 50, September 2007

[21] N. A. Albano, Notarial Archives Malta, $28^{\text {th }}$ September 1588.

[22] S. Mercieca, "St. Paul's departure from Malta," The Times, Malta.

[23] C. G. Scannura, Taghrif Storiku Dwar il-Knisja Parrokkjali ta' Bormla, Bormla, Malta: Kummissjoni Fuljett tal-Kunsill Parrokkjali, 1983, p. 5.

[24] British Museum, London. [Online]. Available: http://www.britishmuseum.org/collectionimages/AN00301/AN00301 394_001_1.jpg http://collection.britishmuseum.org/id/object/PDB10912

[25] M. Buhagiar and S. Fiorini, Mdina, the Cathedral City of Malta: A Reassessment of Its History and a Critical Appreciation of Its Architecture and Works of Art, Malta: Central Bank of Malta, vol. 2, 1996, p. 455.

[26] G. Wettinger, "Honour and shame in late fifteenth century Malta," Melita Historica, vol. 8, no. 1, p. 74, 1980

[27] G. Wettinger, "Acta iuratorum et consilii civitatis et insulae Maltae," Associazione di Studi Malta-Sicilia, no. 217, pp. 239-242, 1993.

[28] G. Wettinger, "The militia list of 1419-20: A new starting point for the study of Malta's population," Melita Historica, vol. 5, no. 2, p. 80, 1969.

[29] G. Wettinger and P. Corrao, Acta Iuratorum et Consilii Civitatis et Insulae Maltae, Publ. Associazione di studi Malta-Sicilia, Centro di studi filologici e linguistici siciliani, 1993, p. 891.

[30] Treccani. (2016). [Online]. http://www.treccani.it/enciclopedia/compagnia/
Available: 
[31] I. Bosio, Dell'Istoria della Sacra Religione et Ill.ma Militia di San Giovanni Gierosolmitano, Parte Terza, Publ. Facciotti, Copy at Bibliotheca Regia Monacensis, (Bayerische Staatsbibliothek), Munich, Bavaria, Germany, 1602, pp. 378-675.

[32] E. S. M. Valledor, Historia de Felipe II, Rey de Espana, 2nd ed. vol. I, chapter XXXIII, P. S. Manero Ed. Barcelona, 1867, p. 383.

[33] F. B. Correggio, The Siege of Malta, 1965, p. 41.

[34] F. Valente and C. Molise. (2008). Gl'architetti di Dio. [Online]. Available:

http://www.francovalente.it/2008/12/08/croci-stazionarie-nel-molise/

[35] S. Vannozzi. (2012). S Maria della Libera di Cercemaggiore - lavori di ristrutturazione edile su beni culturali in nome di un Evento. [Online]. Available:

https://stefanovannozzi.wordpress.com/2012/04/13/s-maria-della-liber a-di-cercemaggiore-lavori-di-ristrutturazione-edile-su-beni-culturali-i n-nome-di-un-evento/

[36] D. L. Porta and R. Russo, Historia della Contea di Molise, Italia: Associazione Culturale Organizzazione Rievocazioni Storiche (ACORS), 2015, p. 55.

[37] C. Carbone, Croci Viarie per le vie del Mondo, Millemetri, 2013, p. 18

[38] F. Valente. (2009). A Roccamandolfi un Cristo Crocifisso con le brage: una rarita' nell'iconografia cristiana medioevale. [Online]. Available: http://www.francovalente.it/2009/10/13/a-roccamandolfi-un-cristo-cr ocifisso-con-le-braghe-una-rarita-nell\%E2\%80\%99iconografia-cristia na-medioevale/

[39] F. Valente, Croci Stazionarie - Nei luoghi antichi del Molise, Italia: La Regia Edizioni, 2012.

[40] R. Francovich and M. Valenti, "Società degli archeologi medievisti italiani," IV Congresso Nazionale di Archeologia Medievale. Firenze, Italia, p. 62, 2006.

[41] Fornaro and Ziccardi, 2014, p. 1-5.

[42] J. Boulanger. (1645). Plan des Forteresse de Vallete, Bourg et Sangle de Malte, Dédiée à son Alt[e]sse Royalle. [Online]. Available: http://gallica.bnf.fr/ark:/12148/btv1b53029428v/f1.item.r=malte.zoom

[43] F. Valente, C. Molise. (2008). Gl'architetti di Dio. [Online]. Available: http://www.francovalente.it/2008/12/08/croci-stazionarie-nel-molise/

[44] E. Kitzinger, Byzantine Art in the Making: Main Lines of Stylistic Development in Mediterranean Art, 3rd-7th Century, Harvard University Press, 1977, p. 115.

[45] JewishHistory. [Online]. Available: https://www.jewishhistory.org/

[46] S. Fiorini, "Malta in 1530," in Hospitaller Malta 1530-1798, V. Mallia-Milanes ed. Msida, Malta: Mireva Publications, 1993, pp. 141-142.

[47] Valletta, Malta, Notary Giuseppe Sammut, Notarial Archives of Malta, vol. 32, 1719.

[48] Maimonides. https://en wikipedia.org/wiki/

[49] A. Brogini, "Rome: Ecole Francaise de Rome," Ritratti di città in Sicilia e a Malta: XVI-XVII secolo, p. 178, 2006.

[50] C. Arnold, The 1565 Ottoman/Malta Campaign Register, Malta, 1998, pp. 19-21.

[51] A. Foglierini, "Parte Moderna o sia continuazione della Storia Universale dal principio del mondo sino al presente, scritta da una compagnia di letterati inglesi; ricavata da' fonti originali, ed illustrata con carte geografiche, rami, note, tavole cronologiche ed altre; tradotta dall'inglese, con giunta di note, e di avvertimenti in alcuni luoghi,' Storia Universale, vol. 55/33, pp. 25-65, 1789.

[52] A. B. Driss, "L'impegno umanitario del sultano Sidi Muhammad ben 'Abd Allah (1757-1790) per l'abolizione della schiavitù in Marocco e in Europa, in Saverio Di Bella e Dario Tomasello," in L'Islam in Europa tra passato e futuro, Cosenza, Italia: Luigi Pellegrini Editore, 2003, pp. 121-129.

[53] G. Wettinger, "The Castrum Maris and its suburb of Birgu during the Middle Ages, in Lino Bugeja, Mario Buhagiar, and Stanley Fiorini,' Birgu - A Maltese Maritime City, Msida, Malta: Malta University Services, Vol. I, 1993, p. 64.

[54] L. A. Bezzina. A short history of the Jews of Malta, [Online]. Available: http://www.angelfire.com/al/AttardBezzinaLawrenc/123.html

[55] T. Gambin, Treasures of Malta, Malta: Fondazzjoni Patrimonju Malti, 2003.

[56] Dinner remains unearthed in dockyard creek, times of Malta. (Dec. 29, $2003)$ [Online].

Available: https://www.timesofmalta.com/articles/view/20031229/local/dinner-r emains-unearthed-in-dockyard-creek.133364

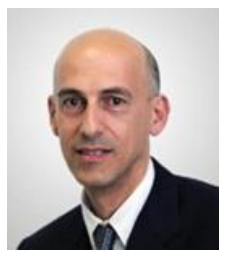

John Vella lives at Bormla, Malta. Vella is a master of science in human resource management and development from the Centre for Labour Studies of the University of Leicester, United Kingdom. Following his MPhil, he is currently a $\mathrm{PhD}$ candidate with the Mediterranean Institute of the University of Malta. His $\mathrm{PhD}$ thesis researches how curators of micro/small grassroots museums interpret and present the communities represented in their museum and the Mediterranean historica imaginary within such museums.

In 1997, together with his mother he founded the independent museum Bir Mula Heritage. Since then his family curates and manages the museum and its activities. His work experiences extend through the public and private sectors in positions as business and product development, tourism, sales and marketing, design, art exhibitions, cultural events and festivals, strategic human resources, management, policies, lecturing and consultancy.

$\mathrm{He}$ authored papers and presented at various conferences on themes as Mediterranean history, oral lore, toponyms, grassroots museology and museum studies. He also co-authored papers with Dr. JosAnn Cutajar senior lectureer and head of the Gender Studies Department, Faculty of Social Well-being, University of Malta - on the impacts of regeneration, museums and pedagogy, museums and communities. His current interests are curatorial practices within grassroots museums, discovering history through ethnohistorical approaches and toponymy, and archaeology.

His social experience includes a nine year service as councillor within the Bormla Local Council and many years as an active volunteer within various local and national groups and associations. 